Pogranicze. Studia Spoleczne. Tom XXIV (2014)

\title{
Jan Poleszczuk
}

UNIWERSYTET W BIA£YMSTOKU

E-MAIL: JAN.POLESZCZUK@GMAIL.COM

\section{RODZINA - WSPÓLNOTA KONFLIKTOWYCH INTERESÓW}

Rodzina jest jedną z podstawowych instytucji, w której realizuje się proces reprodukcji biologicznej, społecznej i kulturowej. W kategoriach tradycyjnej socjologii jest wspólnotą interesów stabilizowanych przez instytucje kulturowe i prawne, związane z jej podstawowymi wymiarami: instytucją małżeństwa, relacji rodzicielskich, problemów związanych z funkcjonowaniem gospodarstwa domowego. W pojęciu wspólnoty jest zakładany konsensus w kwestii kooperacji (wspólnoty interesów i celów), koordynacji (efektywny podział pracy i ról w gospodarstwie domowym), komunikacji (wspólny zespół wartości określający sposoby oceny zachowań, powinności, wzajemne oczekiwania członków rodziny, zaufanie i szacunek). Rodzina jako wspólnota tworzy zintegrowany układ, który można scharakteryzować przez wspólną funkcję produkcji i dystrybucji wartości [Becker 1993]. Ale rodzina (wspólnota) jest złożona z indywiduów, których interesy nie muszą być w doskonałej harmonii, mogą i pojawiają się konflikty związane z percepcją interesów reprodukcyjnych, oceną wkładu pracy i podziałem obowiązków w gospodarstwie domowym, zróżnicowaniem indywidualnych systemów wartości, reakcji poznawczych i emocjonalnych na nieprzewidywalne i traumatyczne zdarzenia (choroby, niepłodność, utrata pracy, niewierność, starość). Wspólnota nie jest instytucjonalnie zagwarantowanym stanem stabilnej równowagi, ale jest wynikiem dynamicznego procesu rozwiązywania konfliktowych interesów. Jeśli się tych interesów nie udaje pogodzić (osiągnąć i utrzymać relacji społecznych w równowadze), rodzina może ulec dezorganizacji lub stać się „układem zamkniętym” generującym najostrzejsze formy patologii społecznej (agresję i przemoc). Z tego punktu widzenia przemiany zachodzące $\mathrm{w}$ rodzinach są najlepszym miejscem obserwacji przemian społecznych i kulturowych w mikroskali i makroskali, gdyż z jednej strony wszystkie „zewnętrzne” napięcia w systemie społecznym (rynek, polityka państwa, mobilność społeczna) są przenoszone na życie rodzinne, a „wewnętrzne" napięcia $\mathrm{w}$ rodzinie są przenoszone $\mathrm{w}$ sferę publiczną 
jako oczekiwania wobec systemu ekonomicznego, prorodzinnej i emerytalnej polityki państwa, szans na realizację własnych aspiracji oraz perspektyw życiowych dzieci. Rodzina, jej struktura i dynamiczne procesy przemian przebiegają $\mathrm{w}$ realnych kontekstach zróżnicowań społecznych związanych z „geografią społeczną", kulturowym i ekonomicznym zróżnicowaniem regionalnym, nierównością rozwoju centrum i peryferii systemu społecznego - czego najważniejszym skutkiem o różnorodnych konsekwencjach społecznych dla integralności wspólnoty rodzinnej są procesy migracyjne. Opis tego złożonego i dynamicznego procesu wymaga wypracowania efektywnych eksplanacyjnie kategorii teoretycznych. Proponuję cztery „perspektywy” opisu rodziny jako wspólnoty konfliktowych interesów. Pierwsza - jest związana z przemianami rodziny w dłuższej perspektywie czasu międzygeneracyjnego, druga - odnosi się do cyklu życiowego (procesy wewnątrzgeneracyjne), trzecia - ujmuje rodzinę w systemie stratyfikacji społecznej i czwarta - opisuje rodzinę jako specyficzny system interakcji społecznych.

\section{Rodzina w perspektywie czasu międzygeneracyjnego}

Rodzina w perspektywie międzygeneracyjnej w sposób naturalny wiąże się z problematyką ewolucyjną, w szczególności problematyką reprodukcyjną zarówno w wymiarze biologicznym (transmisja genetyczna), jak i kulturowym (transmisja memetyczna). We współczesnych ujęciach teoretycznych tradycyjny podział „natura-kultura” traci swą ostrość i występuje w szerokim kontekście złożonej problematyki teoretycznej „podwójnego dziedziczenia”, interakcji genów i memów, ewolucji struktur krewniaczych [Shennan 2002, Boyd, Richerson 2005, 2006]. Rodzina jest fundamentalną ramą reprodukcji, systemem wiążącym instytucję małżeństwa, prokreację, funkcje ekonomiczne w formie gospodarstwa domowego, jest miejscem socjalizacji (transmisji kultury) oraz ważnym czynnikiem stratyfikującym społeczeństwo [Giza-Poleszczuk 2005]. Z perspektywy ewolucyjnej podstawową jednostką analizy procesów reprodukcyjnych (w odniesieniu do gatunku Homo sapiens) jest „para reprodukcyjna”, która w różnych społeczeństwach i kulturach jest usytuowana w szerszych strukturach relacji rodzin, systemów matrymonialnych, więzi krewniaczych. Rodzina, małżeństwo i gospodarstwo domowe stanowiły silne splecione formy instytucjonalne. Dziś „para reprodukcyjna” nie musi jednoznacznie zakładać małżeństwa (monogamii). Z teoretycznego punktu widzenia ważne jest pytanie, kto i za pomocą jakich środków instytucjonalnych kontroluje procesy re- 
produkcyjne? Jest to pytanie o zakres indywidualnej autonomii w decyzjach związanych z reprodukcją. Tradycyjny model, w którym jednostka była silnie uzależniona w swych decyzjach reprodukcyjnych od kontekstu rodzinnego (interesów rodziców, ich usytuowania w strukturze społecznej, kontroli ważnych zasobów niezbędnych do życia), wyraźnie uległ zmianie. Tradycyjna rodzina wielopokoleniowa, silnie rozgałęzione więzi krewniacze („dynastyczne”) zostały zastąpione rodziną nuklearną, która powstaje w wyniku autonomicznych decyzji jednostek zgodnie $\mathrm{z}$ ich osobistymi preferencjami. Jest oczywiście rzeczą dyskusyjną, na ile jest to model opisujący rzeczywistość, na ile zaś projekt kulturowy. Nie ulega jednak wątpliwości, że „przejście demograficzne” [Okólski 2004] spowodowało zmniejszenie dzietności, a co za tym idzie zmniejszył się zasięg relacji krewniaczych, procesy migracyjne do miast znacząco zmieniły sieci wzajemnych relacji w ramach rodzin - z sieci „gęstych” i systematycznych kontaktów relacje rodzinne stały się kontaktami rzadszymi, w większym stopniu zrytualizowanymi (choć w dalszym ciągu mającym ogromną wartość emocjonalną).

Nie jest rzeczą przypadku, że w kontekście tych makrospołecznych przemian, problematyka interesów reprodukcyjnych związanych $\mathrm{z}$ funkcjonowaniem „par reprodukcyjnych” w znacznie silniejszym stopniu została związana z płcią. Nie chodzi w tym przypadku jedynie o klasyczne zagadnienia związane $\mathrm{z}$ emancypacją społeczną kobiet, ale przede wszystkim $\mathrm{z}$ rozpoznaniem odmiennej struktury interesów reprodukcyjnych związanych z odmiennością strategii dostępnych każdej z płci. Przede wszystkim w znacznie większym stopniu uwagę skupia odmienność „zasobów inwestycyjnych”, którymi może dysponować każda $\mathrm{z}$ płci oraz na konsekwencje związane $\mathrm{z}$ doborem partnerskim i decyzjami prokreacyjnymi [Woodward, Richards 2005; Geary 2005; Yamauchi 2010; Park 2010]. Mimo znaczących zmian kulturowych konsekwencje nietrafnych decyzji nie są dystrybuowane egalitarnie - większe ryzyko nadal ponoszą kobiety. Muszą być w swych decyzjach ostrożniejsze, podlegać również będą silniejszej kontroli społecznej ze strony krewnych. Zasoby inwestycyjne mają nie tylko charakter biologiczny, ale również społeczny; są to wszystkie czynniki, jakie może pozyskać jednostka w celu przeznaczenia ich na funkcjonowanie rodziny (zasoby ekonomiczne, prestiż, władza - czyli klasyczne czynniki statusowe). Dobór partnerski nie jest procesem losowym - ma on istotne teoretyczne ugruntowanie w preferencjach związanych z efektywnością procesów reprodukcyjnych [Seather 1998; Ryan 1998; Andersson 2006]. W efekcie asortatywnego doboru partnerskiego zwiększa się w populacji zróżnicowanie (wariancja) zasobów, którymi dysponuje „para reprodukcyjna”, a więc w efekcie zwiększa się również zróżnicowanie szans życiowych potomstwa, które 
uzyskuje na starcie większe wyposażenie w dobra materialne, opiekę, edukację. Decyzje o tym kto z kim może zawiązać efektywny układ reprodukcyjny zależą od posiadanej informacji i jej wartości predyktywnej. Można zaryzykować hipotezę, że nowoczesny ład reprodukcyjny stwarza poważne kłopoty w pozyskiwaniu wartościowej informacji. W dużej mierze zmiany kulturowe dające duże możliwości „autokreacji” sprawiają, że informacja może nie być wiarygodna jako charakterystyka indywidualnej wartości potencjalnego partnera. Dynamiczne zmiany kulturowe w ciągu jednego pokolenia sprawiają, że „dobre wzorce” rodziców nie są użyteczne lub trudne do przyjęcia. Zatem proces doboru partnerskiego może przyjmować charakter przypadkowy z dużym ryzykiem błędu. W konsekwencji można się spodziewać większej częstości rozpadu związków i w związku z tym mniejszej dzietności. Być może odkładanie zawarcia małżeństwa lub rezygnacja z tej „instytucji” jest rozsądną strategią adaptacyjną do niepewnego kontekstu - zmniejsza koszty wyjścia z niesatysfakcjonującego związku. Niezależnie od tych problemów kwestia nierówności zasobów inwestycyjnych jest ważnym czynnikiem stabilności małżeństwa lub związku partnerskiego. Z pewnością ma znaczenie w procesach negocjacji ról społecznych pełnionych w rodzinie, podziału pracy, zakresu odpowiedzialności; jest istotnym czynnikiem wyznaczającym „siłę przetargową” jednostki w gospodarstwie domowym [Park 2007]. Podstawowe znaczenie w określaniu „siły przetargowej” zaczyna mieć również zakres i charakter szans na rynku pracy; związany z wysokością i stabilnością strumienia pozyskiwanych środków ekonomicznych.

O ile jednak transgeneracyjny proces reprodukcji (rodzice-dzieci) wymaga stabilności w perspektywie dziesięcioleci, o tyle zmienność (nieprzewidywalność) sytuacji rynkowej może być znaczącym źródłem „zewnętrznych” napięć związanych z szansami na znalezienie pracy, ryzykiem jej utraty w związku ze zmianami koniunktury. Tak znaczącej elastyczności mogą podlegać decyzje prokreacyjne (z kim, kiedy i ile mieć dzieci), ale kontrola procesu prokreacyjnego wymaga przygotowania kulturowego oraz dostępu do efektywnej antykoncepcji. W efekcie duża niestabilność zewnętrznych uwarunkować procesów reprodukcyjnych przy niedostatecznych mechanizmach kontroli skutkować może trudną do przełamania „reprodukcją biedy”.

Rodzina - związki krewniacze - tracą na znaczeniu jako społeczne akceptowalne strategie dostępu do dóbr rzadkich, dystrybucji szans życiowych i opieki - w szczególności, gdy związane są one ze sferą publiczną (nepotyzm). Z pokolenia na pokolenie większego znaczenia nabierają instytucje zewnętrzne przejmujące kontrolę nad opieką nad dziećmi, ich zdrowiem, edukacją oraz opieką nad ludźmi starymi. Wydaje się, że proces reprodukcji i transmisji mię- 
dzygeneracyjnej zostaje $\mathrm{w}$ większym stopniu przeniesiony $\mathrm{z}$ kontekstu rodziny w kontekst instytucjonalny. Od jego stabilności zależy ciągłość reprodukcji społecznej i kulturowej, ale również postrzeganie rodziny, w której uważniej monitoruje się procesy dysfunkcjonalne (przemoc wobec dzieci i osób starszych), [Kramkowska 2014]. Rodzina - w swej tradycyjnej formie - traci na znaczeniu, ale nie znaczy to, że procesy reprodukcyjne są mniej istotne. Przeciwnie, uzależnienie procesów reprodukcyjnych rodziny od zewnętrznego kontekstu instytucjonalnego sprawia, że zasady jego funkcjonowania, problemy równości szans i sprawiedliwości dystrybucji zasobów, problemy równości płci, problemy kontroli procesu reprodukcyjnego - stają się zasadniczym przedmiotem debaty politycznej. Powinny być również podstawowym przedmiotem badań nauk społecznych (socjologii, ekonomii, demografii).

\section{Fazy życia - rodzina w perspektywie wewnątrzgeneracyjnej}

Teoria cyklu życiowego jest konstruktem teoretycznym dzielącym życie jednostki na fazy, które charakteryzują się odmienną strukturą problemów wynikających z odmiennych wyzwań, z jakimi ma do czynienia jednostka. Teoretyczną podstawą jest złożenie dwóch podstawowych parametrów demograficznych: procesu przeżywalności i prokreacji [Sotomayor-Peterson 2013]. Patrząc na dowolnie wybraną kohortę osób urodzonych w danym przedziale czasu, możemy zauważyć, że wraz z jego upływem kohorta się „wykrusza” (choroby, wypadki i wiek) - wielość kohorty jest nierosnącą funkcją wieku. W tym czasie jednostka dojrzewa, podejmuje wysiłek reprodukcyjny i wchodzi w okres starości. Złożenie tych dwóch procesów określa wartość reprodukcyjną jednostki w danym wieku (EEEM 1998). Narodziny i śmierć wyznaczają naturalne ramy czasu wewnątrzgeneracyjnego, ale jego poszczególne fazy podlegają istotnym wpływom ekologicznym i kulturowym.

W fazie I - przedreprodukcyjnej - podstawowym zadaniem jednostki jest rozwój fenotypu - ogółu własności, które charakteryzują jej kondycję fizyczną i umysłową. W tej fazie występuje silna interakcja czynników genetycznych dziedziczonych po rodzicach oraz czynników społeczno-kulturowych składających się na proces socjalizacji pierwotnej. Żadna cecha nie jest wyłącznie efektem oddziaływania genów lub środowiska. Wyposażenie genetyczne może określać pewną skalę absorpcji czynników kulturowych, ale również czynniki środowiska mogą modyfikować istotnie wpływ genów (mechanizmy epigenetyczne). Z socjologicznego punktu widzenia istotne jest to, że każda wyjściowa 
kohorta (generacja) jest zróżnicowana, a zróżnicowanie to wpływa znacząco na dalsze szanse życiowe jednostki - niewielkie w punkcie startu różnice ulegną amplifikacji i przekształcą się w różne ścieżki historii życia. Jeśli rodzice dobierają się w pary reprodukcyjne nielosowo ze względu na charakterystyki społeczne (status, zasoby materialne), psychologiczne (IQ) oraz biologiczne (wzrost, cechy związane z kondycją biologiczną), to znaczy, że zróżnicowanie dzieci - jeśli jest dziedziczone - jest konsekwencją zróżnicowania genotypów, psychotypów i socjotypów rodziców oraz korelacji tych wymiarów (dobór asortatywny). Innymi słowy, „struktura społeczna” jest czynnikiem zwiększającym zróżnicowanie, a więc zwiększającym potencjał selekcyjny. Z tego punktu widzenia ewolucja społeczna i kulturowa jest nie tylko przedłużeniem procesów biologicznych, ale wpływa na przyspieszenie ich tempa [Cochran, Harpending 2009]. W tej fazie jednostka przyjmuje rolę „dziecka” i jest przedmiotem rozległych praktyk socjalizacyjnych - zarówno w rodzinie, jak i instytucjach (przedszkole, szkoła). Jest to również faza, w której dokonuje się zasadnicza transmisja kultury, ale jest to transmisja kultury przefiltrowana przez strukturę społeczną, decydującą o zakresie i wartości „kapitałów” (społecznych i kulturowych), jakie otrzyma jednostka do swej dyspozycji. Być może jedną z najważniejszych innowacji adaptacyjnych człowieka jest niezwykła umiejętność imitacji i uczenia się przez instrukcje [Simon 1979; Rizzolatti, Sinigaglia 2008].

Faza II cyklu życiowego to intensywny okres wychodzenia poza ramy rodziny. W tej fazie szczególnie zaznaczają się procesy formowania własnej tożsamości, pozycji w grupie rówieśniczej - jednostka rozpoznaje swoją wartość (atrakcyjność) w różnych konfiguracjach społecznych: grupy rówieśnicze, szkoła, organizacje społeczne. Proces nie zawsze przebiega w sposób łagodny. Agresja w szkołach jest zjawiskiem dość powszechnym (około 10\% młodych ludzi doświadcza dręczenia szkolnego [Komendant-Brodowska 2013]). Rodzina jest w stanie pełnić funkcję wspierającą jedynie w ograniczonym zakresie. W tym czasie pojawiają się „alternatywne źródła autorytetu” znacznie silniej oddziałujące na poglądy i postawy młodzieży. Jest to również faza inicjacji seksualnej, w tym zaś względzie rodzice nie odgrywają znaczącej roli.

Faza III - faza osiągnięcia dojrzałości, w czasie której jednostka wchodzi w okres reprodukcyjny i podlega silnym presjom związanym $\mathrm{z}$ doborem partnerskim ukierunkowanym na decyzje prokreacyjne. Rozpoczyna się okres intensywnych inwestycji rodzicielskich, który zbiega się również z presjami związanymi z aktywizacją zawodową, początkiem karier. Początek tej fazy nie jest jednoznacznie zdefiniowany. W ramach ogólnej teorii konfliktów rodzicielskich [Godfray 1995] można oczekiwać, że o usamodzielnieniu się potomstwa decydować będzie „układ sił” - dzieci mogą mieć interes w korzystaniu z in- 
westycji rodzicielskich, zwłaszcza gdy ich osobiste szanse życiowe nie przedstawiają się pomyślnie. Faza II, szczególnie zaś III odsłaniają również odmienność sytuacji kobiet i mężczyzn. Mężczyźni mogą opóźniać czas zawiązania rodziny, dążąc do osiągnięcia wysokiej pozycji społecznej. Starsi mężczyźni dysponujący znaczącymi zasobami, zajmujący wysokie pozycje w hierarchii społecznej nie tracą na atrakcyjności na rynku matrymonialnym. Czas w przypadku kobiet jest czynnikiem silniej ograniczającym pole decyzji. Wysoki status nie jest efektywną strategią na pozyskanie partnera, a wiek zdecydowanie silniej obniża atrakcyjność reprodukcyjną kobiet. Dziś epitety „stara panna” i „stary kawaler” nie mają już znaczenia stygmatyzującego, choć problemy związane z tymi kategoriami nie zniknęly.

Faza IV - to faza postreprodukyjna. Dzieci się usamodzielniają, „para reprodukcyjna" pozostaje w pustym domu, aby spędzić ze sobą dalsze 20-30 lat. Przemiany struktury rodziny (mniejsza liczba dzieci, wnuków), migracje, słabnąca więź - może sprawiać, że wydłużająca się faza starości stanie się jednym z głównych problemów społecznych społeczeństw współczesnych, wymagających rozwiązań instytucjonalnych (aktywizacji, przeciwdziałania samotności i wykluczeniu). Fundusze emerytalne, profesjonalna opieka społeczna i medyczna sprawiają, że rodzina przestaje być niezbędnym czynnikiem bezpieczeństwa na starość, a starość obciążeniem dla młodych rodzin (z fazy III). Ale wydłużająca się faza postreprodukcyjna może - w przypadku niedorozwoju infrastruktury instytucjonalnej - mieć swoje negatywne konsekwencje, szczególnie w społecznościach tradycyjnych, które przechodzą gwałtowną zmianę modernizacyjną [Kramkowska 2014].

To „fazowe” ujęcie dynamiki życia jednostki i rodziny, z której się ona wywodzi oraz którą tworzy, pokazuje niezwykłą dynamiczną złożoność indywidualnych historii życia. W fazie socjalizacji rodziny ujawniają się konflikty między rodzicami i dziećmi oraz między rodzeństwem (choć zmniejszająca się liczba dzieci łagodzi strukturalne źródła tego typu konfliktów). W fazie dojrzewania problemem staje się kontrola nad dziećmi, ich zachowaniami, relacjami społecznymi. Pozostawać mogą one poza zasięgiem wzroku rodziców, którzy zderzają się również z alternatywnymi źródłami autorytetu (grupy rówieśnicze, szkoła, media). Usamodzielnianie się dzieci wiąże się również z doświadczeniem barier wejścia na rynek pracy, stabilnością zatrudnienia, wysokością strumienia dochodów, które mogą nie wystarczać do zaspokojenia aspiracji i przyjętego stylu życia kreowanego przez współczesne media. I na koniec faza starości, przedłużająca się i silnie uzależniająca od kontekstu instytucjonalnego poza rodziną. Człowiek stary stać się może obciążeniem i źródłem konfliktów w rodzinie. Rodzina w perspektywie wewnątrzgeneracyjnej jest dynamicznym 
procesem radzenia sobie z wyzwaniami cyklu życiowego. Problem w tym, że każdy błąd, deficyt, porażka na wcześniejszym etapie cyklu może mieć trudny do przewidzenia efekt skumulowany, przez który - w postaci awansu lub degradacji społecznej - reprodukuje się struktura społeczna. Nie wszystkie konsekwencje błędnych wyborów są odwracalne.

\section{Rodzina w systemie stratyfikacji społecznej}

Stratyfikacja społeczna jest dla rodziny szczególnie istotną ramą odniesienia, gdyż rodzina nie tylko jest ulokowana na jakimś „,szczeblu drabiny społecznej”, ale jest również ważnym czynnikiem osiągania tej pozycji oraz jej utrzymania. Trzy tradycyjnie wyróżniane wymiary stratyfikacji: bogactwo, władza i prestiż, we współczesnej socjologii zostały uogólnione w postaci trzech typów „kapitałów”: kapitału ekonomicznego, określonego przez szanse na rynku pracy, zdolnością w kontroli strumienia zasobów ekonomicznych; kapitału społecznego - struktury relacji społecznych (formalnych i nieformalnych) oraz kapitału kulturowego - ogółu kompetencji niezbędnych do efektywnego poruszania się w przestrzeni instytucjonalnej. Rodzina umiejscowiona w strukturze społecznej jest w dużej mierze „producentem” tych kapitałów w postaci wspólnego gospodarstwa domowego, więzi krewniaczych i społecznych, wsparcia w procesie socjalizacji kulturowej i aspiracji w osiąganiu wyższego poziomu edukacji. Dystrybucja tych kapitałów, ich korelacja oraz mechanizmy konwersji - określają pozycję i rolę rodziny w systemie stratyfikacji społecznej. Rodzina stanowi formę i mechanizm dystrybucji „dóbr rzadkich” w systemie społecznym. To od tego, jaka jest liczebność rodziny, osiągnięty poziom i różnorodność wykształcenia jej członków, dochody, miejsce zamieszkania i przestrzenne rozproszenie zależy również oczekiwana długość życia, poziom zdrowia i ryzyko chorób, styl życia.

System stratyfikacji jest silnie związany z dwiema wcześniej opisanymi perspektywami: czasu międzygeneracyjnego i cyklu życia. Nie jest to tylko statyczna postać zróżnicowania, ale dynamiczna postać nierówności społecznych. Jeśli stratyfikacja jest pewnego typu „drabiną społeczną”, to pozycje na tej drabinie silnie są skorelowane z szansami kontrolowania dostępu do odpowiednich kapitałów. Na szczycie drabiny znajdują się „elity” społeczne, na najniższych szczeblach - ludzie „zmarginalizowani”, czasem całkowicie wyrzuceni poza nawias systemu społecznego. Między szczeblami odbywa się mniej lub bardziej zauważalny ruch - jednostki pną się na drabinie społecznej (awans) lub spa- 
dają (degradacja). Proces mobilności może przybierać w szczególnych okolicznościach historycznych charakter rewolucyjny, w którym pozycja indywidualna zależy silnie od przynależności do warstwy lub klasy społecznej. W czasach mniej gwałtownych przemian awans jednostki może być uzależniony od kapitału społecznego rodziny (rozległości sieci wsparcia, znajomości), kapitału kulturowego, którego znaczenie wzrasta w przypadku procesów migracyjnych, i ekonomicznego. Rodzina może być poważną barierą w procesie mobilności, gdyż to w rodzinie nie tylko kształtują się aspiracje młodych ludzi, ale również motywacje rodziców do inwestowania w przyszłość dzieci. W przypadku rodzin „zasiedlających” wyższe piętra struktury społecznej rodzinna może pełnić niezwykle ważną funkcję przeciwdziałania degradacji poprzez kontrolę nad zachowaniem, wspieranie - stając się swoistą "polisą ubezpieczeniową".

Mobilność wertykalna jest niezwykle interesującym procesem w perspektywie praktyk socjalizacyjnych. Rodzice, którzy sami osiągnęli awans, często nie dysponują wiedzą i nie mają motywacji do tego, aby uczyć i wymuszać na dzieciach zachowania prowadzące do zachowania osiągniętej pozycji - można się więc spodziewać, że dzieci pierwszego pokolenia rodziców z awansu mogą być narażone na większe ryzyko degradacji. W efekcie struktura społeczna szczególnie w perspektywie dynamiki cyklu życiowego - to zróżnicowana skala „entropii”: z jednej strony, gdy przesuwamy się w wyższe regiony struktury społecznej, obserwujemy zwiększające się skorelowanie kapitałów (czynników statusu) - aktywności na rynku pracy, rozległości sieci społecznych, różnorodności kompetencji kulturowych, z drugiej natomiast częściej jest realizowany wzorzec „singla”, rodziny patchworkowej, odkładanie małżeństw lub utrzymywanie rodziny w postaci związków partnerskich. Przemiany tradycyjnych wzorców rodzinnych (podziału pracy, definicji ról społecznych, obowiązków) sprawiają, że rodzina przestaje być postrzegana jako istotny czynnik stabilizacji historii życia - przeciwnie, często jest narażana na przeniesienie napięć z otoczenia instytucjonalnego (rynek). Co więcej, zanik rozległych społecznie form rytualnych związanych z małżeństwem i rodziną sprawia, że traci ona status instytucji, stając się indywidualnym kontraktem [Rhoades, Scott 2014]. Mimo że zachodzą istotne zmiany w „sztywności” struktury społecznej nadal można obserwować silne podziałały stylu życia rodzin na wsi i mieście, zakresu „wtórnego rynku matrymonialnego" związanego z rozwodami, zróżnicowanie cyklu życiowego, dzietności, czy funkcjonowania takich kategorii jak „stara panna”, „stary kawaler” czy „mezalians”. Struktura społeczna się demokratyzuje, ale nie znaczy, że zanika, że zachowania ludzi w sferze reprodukcyjnej stają się losowe (przypadkowe). Wiek, miejsce zamieszkania, zdrowie, „zasoby kapitałowe”, w tym również IQ - nadal odgrywają zasadniczą rolę w doborze partnerskim, 
procesach awansu społecznego, wpływają na ryzyko degradacji, a w konsekwencji na patologiczne zachowania (alkoholizm, samobójstwa) czy położenie społeczne (wykluczenie, samotność, bezdomność).

\section{Rodzina jako system interakcji społecznych}

Rodzina tworzy względnie autonomiczny system interakcji społecznych, w którym dokonuje się reprodukcja biologiczna populacji oraz transmisja jej kultury. Warto zwrócić jednak uwagę na kilka istotnych cech strukturalnych, z których można utworzyć pewnego rodzaju „typ idealny” instytucji. W odróżnieniu od innych układów społecznych, interakcje w rodzinie cechują się wysokim stopniem powtarzalności w stosunkowo małej grupie osób. Interakcje mają charakter całościowy - w życiu rodziny nie uczestniczy się aspektowo, w wyznaczonym miejscu lub czasie, $\mathrm{z}$ dobrze określonymi granicami oczekiwań i powinności. W rezultacie jednostki dysponują ogromnymi zasobami wiedzy o sobie wzajemnie, wiedzy uzyskiwanej w wielu sytuacjach konfliktowych, związanych z koniecznością rozwiązywania problemów egzystencjalnych, ujawniania i uzgadniania preferencji, priorytetów, wzajemnej pomocy. Z jednej strony jest to podstawa zawiązywania się silnej więzi emocjonalnej przez wykształcanie i wzajemne rozpoznawanie potrzeb i przyzwyczajeń. Z drugiej strony jednak w przypadku wystąpienia konfliktów (konfliktów preferencji, interesów, systemów motywacyjnych) powtarzalność interakcji stać się może istotnym czynnikiem eskalacji konfliktów, wzmacniania się agresji przez utrzymywanie w pamięci doznawanych krzywd, umiejętności wyrządzania krzywd dzięki wiedzy o „słabych punktach” osób, które się dobrze zna. Nie jest rzeczą przypadku, że znaczna część zachowań dewiacyjnych (związanych z różnorodnymi formami przemocy) ma miejsce $\mathrm{w}$ rodzinie i nie jest łatwo przerwać eskalację konfliktu. Konfliktowe interesy mogą być ograniczane przez wspólne interesy reprodukcyjne. Mimo że rodzina jest silną strukturą relacji krewniaczych [Giza-Poleszczuk 2005; KS 2010], to jednak ograniczenia nakładane przez teorię ewolucyjną na działanie pokrewieństwa mają charakter warunkowy i nie eliminują całkowicie przestrzeni konfliktów.

Rodzina - z uwagi na międzygeneracyjny wymiar procesu reprodukcji - jest również jednym z podstawowych modeli organizacji hierarchicznej. Istotnym teoretycznie faktem jest to, że wewnętrza przestrzeń rodziny jako systemu interakcyjnego tworzy specyficzny model prywatnej przestrzeni publicznej. Życie rodziny jest mniej lub silniej izolowane (przestrzeń prywatna), ale członkowie 
rodziny uczestniczą w rytuałach wytwarzania między sobą wspólnej wiedzy, wiedzy dostępnej wszystkim członkom rodziny [Anuszewska 2007]. Również $\mathrm{w}$ rodzinie $\mathrm{w}$ mniejszym lub większym stopniu respektuje się sferę osobistą, niemniej zrytualizowane i zrutynizowane formy wspólnego życia (świętowania, wspólnych posiłków, wspólnej pracy, korzystania ze wspólnej przestrzeni) wytwarzają silną identyfikację z innymi członkami rodziny - wspólnoty. Rodzina jest więc podstawową instytucją nie tylko reprodukcji (dzieci), transmisji kapitałów (ekonomicznych, społecznych i kulturowych), ale przede wszystkim miejscem, w którym wytwarza się podstawowy kod moralny, złożony z elementarnych zasad lojalności i zaufania. Zaufanie i lojalność jest oczywiście niezwykle ważne w kształtowaniu stabilnej relacji między dorosłymi, ale również $\mathrm{w}$ relacjach $\mathrm{z}$ dziećmi oraz relacji między rodzeństwem. $\mathrm{Z}$ tego punktu widzenia zawężanie się rozległych sieci relacji krewniaczych do form rodziny nuklearnej, zmniejszanie się liczby dzieci, wielkokrotne zawieranie małżeństw lub zawiązywanie związków partnerskich tworzących rodziny patchworkowe prowadzić może do znaczących przemian kulturowych na poziomie organizacji reguł życia społecznego. Z pewnością jest to proces osłabiający znaczenie i siłę tradycyjnego nepotyzmu i uzależniający rozwój kompetencji społecznych od wpływu innych, pozarodzinnych czynników (przedszkole, szkoła, media). Z drugiej strony można postawić pytanie, na ile elementarne zasady lojalności i zaufania można przenieść na układy niemające charakteru rodzinnego: czy są one również stabilne lub - przeciwnie - mogą być poddane niekontrolowanej przez jednostkę manipulacji. Tradycyjna rodzina jest społecznym instrumentem kontroli zachowania swych członków. Gdy w wyniku gwałtownych przemian społecznych ulega ona szybkiej ewolucji, kod moralny oparty na lojalności i zaufaniu przeniesiony do innych instytucji (organizacji) może być podłożem destrukcyjnych emocjonalnie i poznawczo działań. O ile tradycyjna rodzina (w szczególności rodziny zajmujące wysokie pozycje społeczne) tworzą zamknięte układy (wspólnoty interesów), do których koszty wejścia i wyjścia są wysokie, o tyle przemiany społeczne prowadzą do znaczącego osłabienia tych układów przez spadające koszty zawiązania i rozwiązania układu' ${ }^{1}$. Co więcej choć wygląda to na paradoks - zewnętrzne instytucjonalne działania wspomagania rodziny, kontroli, wyrównywania szans mogą osłabiać tradycyjne wzorce radzenia sobie z problemem integracji rodziny, jej stabilności, znaczenia w organizacji kapitałów wspierających się członków wspólnoty.

Rodzina jest systemem interakcji i jak każdy system musi umieć radzić sobie z problemem zakłócenia równowagi. Zaufanie i lojalność, solidarność w ro-

Zarys ujęcia instytucji w kategoriach kosztów wejścia i wyjścia [Poleszczuk 2011] 
dzinie mogą zakłócić różnorodne czynniki od zdrady małżeńskiej, utraty pracy czy pozycji społecznej, wypadków po przewlekłe choroby (partnera lub dzieci). Z tymi problemami muszą sobie umieć radzić członkowie wspólnoty. Mogą - o ile zechcą i są takie możliwości - skorzystać ze wsparcia instytucjonalnego, ale często nie umieją, gdyż zawężające się sieci rodzinne nie dostarczają efektywnych wzorców stosowania sankcji, zachowań pozwalających na wyjście z kryzysu oraz stabilizacji kompromisu, zgody. Odtworzenie stabilnej równowagi wspólnoty, w której doszło do naruszenia podstawowych zasad lojalności i zaufania jest zadaniem trudnym i często nieosiągalnym, niezależnie od pozycji społecznej lub inteligencji „aktorów”. Większa niestabilność wspólnot rodzinnych na wyższych piętrach drabiny społecznej nie wynika, jak sądzę, z przemian wartości (kariera jest ważniejsza niż rodzina, małżeństwo to przestarzała instytucja, związki partnerskie są autentyczne, bycie singlem to wybór życiowy), ale z niedostatku kompetencji kulturowych $\mathrm{w}$ radzeniu sobie $\mathrm{z}$ realnymi konfliktami, które są nieodłącznym wymiarem funkcjonowania wspólnot rodzinnych.

\section{Zakończenie}

Przedstawione perspektywy teoretyczne patrzenia na rodzinę nie wyczerpują bogactwa problematyki empirycznej. Są raczej propozycją uporządkowania kategorii (modeli) teoretycznych, w których opisuje się rodzinę, jej przemiany, sposoby adaptacji do zmieniających się warunków. Rodzina w perspektywie międzygeneracyjnej to w dużej mierze instytucja reprodukcji biologicznej i kulturowej. Rodzina w perspektywie cyklu życiowego to dynamicznie zmieniająca się struktura "problemów do rozwiązania” związanych z fazami cyklu: fazą socjalizacji, doboru partnerskiego (matingu), reprodukcji (faza rodzicielstwa) i fazą senioralną. Zmienia się zasadniczo struktura interesów (dążeń), dostępnych zasobów (czas życia), charakter relacji społecznych, definicji ról. Rodzina w systemie stratyfikacji społecznej jest związana z pozycją w systemie dystrybucji dóbr rzadkich (kapitałów). I rodzina jako system interakcji społecznych jest złożonym dynamicznie układem zależności, w których kształtują się i stabilizują podstawowe struktury kodu moralnego: postawy lojalności i zaufania. Wyodrębnione perspektywy nie są od siebie niezależne. To, jak wpływają na siebie jest kwestią badań empirycznych weryfikujących modele teoretyczne. Rodzina - małżeństwo i gospodarstwo domowe - tworzą układ instytucjonalny, w którym realizuje się wspólne interesy reprodukcyjne, ale nie 
zawsze są one zgodne: w ramach tego wspólnotowego układu mogą wystąpić konflikty. Przedstawione perspektywy modelowania dynamiki układu pozwalają rozpoznać uwarunkowania i następstwa tych konfliktów.

\section{Bibliografia}

Andersson M. [2006] Sexual selection and mate choice, "Trends in ecology and evolution" 2006, nr 21: 296-302

Anuszewska I. [2007] Wspólna wiedza: intuicje potoczne i ujęcie formalne, „Decyzje” 2007, nr 8 Becker G. S. [1993] A Treatise on the Family, Harvard University Press

Boyd R., Richerson P. J. [2005] The Origin and Evolution of Cultures, Oxford

Cochran G., Harpending H. [2009] The 10,000 Year Explosion: How Civilization Accelerated Human Evolution, New York

EEEM [1998] The Encyclopedia of Ecology and Environmental Management, Blackwell Science

Geary D. C. [2005] Evolution of paternal investment, [w:] W. D. M. Buss (red.), The handbook of evolutionary psychology, New York: 483-505

Giza-Poleszczuk A. [2005] Rodzina a system społeczny. Reprodukcja a kooperacja w perspektywie interdyscyplinarnej, Warszawa

Godfray H. C. J. [1995] Evolutionary theory of parent-offspring conflict, , Nature” 07, nr 376

Komendant-Brodowska A. [2013] Między głosem sumienia a więzami przyjaźni. Zachowanie świadków dręczenia (bullying) a struktura klasy szkolnej, „Decyzje” 2013, nr 20

Kramkowska E. [2014] Człowiek stary jako ofiara przemocy w rodzinie, rozprawa doktorska, Białystok

Okólski M. [2004] Demografia zmiany społecznej, Warszawa

Park Ch. [2007] Marriage Market, Parents' Bargaining Powers, and Children's Nutrition and Education, "Oxford Bulletin of Economics and Statistics" nr 12

Park S. The effect of paternal investment on female fertility intention in South Korea, "Evolution and human behavior" 2010: 447-452

Poleszczuk J., [2011] Konfiguracyjny model procesu strukturacji społecznej, [w:] P. Gliński, I. Sadowski, A. Zawistowska (red.), Kulturowe aspekty struktury społecznej, Białystok, s. 137-148.

Rhoades G. K., Scott M. S. [2014] Before "I Do". What Do Premarital Experiences Have to Do with Marital Quality Among Today's Young Adults? The National Marriage Project University of Virginia

Richerson P. J., Boyd R. [2006] Not By Genes Alone: How Culture Transformed Human Evolution. Chicago

Rizzolatti G., Sinigaglia C. [2008] Mirrors in the Brain. How We Share our Actions and Emotions, Oxford

Ryan M. [1998] Sexual selection, receiver biases, and the evolution of sex differences, "Science" 281 
Sæther F. [1998] Beauty is in the eye of the beholder: causes and consequences of variation in mating preferences "Trends in ecology and evolution" nr 14

Shennan S. J. [2002] Genes, Memes and Human History: Darwinian Archaeology and Cultural Evolution, London

Simon H. A. [1997] A Mechanism for Social Selection and Successful Altruism, "Models of bounded rationality" nr 3

Sotomayor-Peterson M., De Baca T., Figueredo A. [2013] Shared Parenting, Parental Effort, and Life History Strategy, "A Cross-Cultural Comparison Journal of Cross-Cultural Psychology" nr 4

Woodward K., Richards M. H. [2005] The parental investment model and minimum mate choice criteria in humans, "Behavioral Ecology" nr 1: 57-61

Yamauchi, Ch. [2010 ] Parental investment in children: differential pathways of parentaleducation and mental health, ,,The Economic Record” 2010, t. 86, nr 273 


\section{SUMMARY}

\section{Family as a Community of Conflicting Interests}

The article presents four perspectives on the family. In the intergenerational perspective a family is an institution of biological and cultural reproduction. Family in the perspective of the life cycle is a dynamically changing structure of "problems to solve" associated with life cycle: socialization, mating, parenting and post reproductive phase. Each phase substantially changes the structure of interests, available resources and the nature of social relationships. Family in the system of social stratification is associated with the distribution of scarce resources. The family as a system of social interaction is a complex dynamic unit which stabilizes the basic structure of the moral code (attitudes of loyalty and trust).

Keywords:

family, life cycle, social stratification, reproduction 